\begin{tabular}{|l|l|l||}
\hline \multicolumn{2}{|c|}{ PublisherInfo } \\
\hline \hline PublisherName & $:$ & BioMed Central \\
\hline \hline PublisherLocation & $:$ & London \\
\hline \hline PublisherImprintName & $:$ & BioMed Central \\
\hline \hline
\end{tabular}

\title{
Symbiont genome
}

\begin{tabular}{|l|l|l||}
\hline \multicolumn{2}{|c|}{ ArticleInfo } \\
\hline \hline ArticleID & $:$ & 4673 \\
\hline \hline ArticleDOI & $:$ & $10.1186 /$ gb-spotlight-20030109-01 \\
\hline \hline ArticleCitationID & $:$ & spotlight-20030109-01 \\
\hline \hline ArticleSequenceNumber & $:$ & 25 \\
\hline \hline ArticleCategory & $:$ & Research news \\
\hline ArticleFirstPage & $:$ & 1 \\
\hline \hline ArticleLastPage & $:$ & 2 \\
\hline \hline & & RegistrationDate : 2003-1-9 \\
\hline ArticleHistory & $:$ & OnlineDate \\
\hline \hline ArticleCopyright & $:$ & BioMed Central Ltd2003-1-9 \\
\hline \hline ArticleGrants & $:$ & \\
\hline \hline ArticleContext & $:$ & 130594411 \\
\hline \hline
\end{tabular}




\section{Jonathan B Weitzman}

Email: jonathanweitzman@hotmail.com

In the Early Edition of the Proceedings of the National Academy of Sciences van Ham et al. report the sequencing of the genome of the intracellular symbiont Buchnera aphidicola from the aphid Baizongia pistacea (BBp) (Proc Natl Acad Sci USA 2002, 10.1073/pnas.02359811). As neither bacteria nor the host can be easily cultured in the laboratory, insects were collected from the field (from galls of a natural population on Pistacia trees), and bacterial DNA was then isolated for whole-genome shotgun sequencing. The BBp genome consists of a $616 \mathrm{~kb}$ chromosome and a 2,399 bp plasmid, containing 544 putative genes and nine pseudogenes. In addition, van Ham et al. found extensive intra-population variation and over 1,000 dimorphic SNPs. Comparison with two other sequenced Buchnera genomes revealed almost perfect chromosomal synteny; $78 \%$ of genes are present in all three genomes.

\section{References}

1. Proceedings of the National Academy of Sciences, [http://www.pnas.org]

2. Genetics, physiology, and evolutionary relationships of the genus Buchnera: intracellular symbionts of aphids. 